International Journal of Computer Engineering and Technology (IJCET)

Volume 10, Issue 03, May-June 2019, pp. 45-59, Article ID: IJCET 1003006

Available online at http://iaeme.com/Home/issue/IJCET?Volume $=10 \&$ Issue $=3$

Journal Impact Factor (2019): 10.5167 (Calculated by GISI) www.jifactor.com

ISSN Print: 0976-6367 and ISSN Online: 0976-6375

(C) IAEME Publication

\title{
COMPREHENSIVE STUDY OF HYPERSPECTRL SIGNATURES, PETROGRAPHY AND EDX ANALYSIS ON GOLD BEARING LITHO UNITS OF KEMPINAKOTE, NUGGIHALLI SCHIST BELT, DHARWAR CRATON, KARNATAKA, INDIA
}

\author{
Abrar Ahmed, Maruthi N.E and H.T. Basavarajappa \\ Department of Studies in Earth Science, Centre for Advanced Studies in Precambrian \\ Geology, University of Mysore, Manasagangothri, Mysuru, Karnataka, India
}

\begin{abstract}
The Archean Green Stone Belts (AGSB) having enormous metalliferous deposits like gold, copper, silver, iron and other precious gem stones which are also called as schist belts of Dharwar Craton. The study area Kempinakote lies in southern most part of Nuggihalli Schist Belt of Hassan district. The schist belt consists commonly two rock types Amphibolites and Ultramafics with their variants. Gold is occurring at or near the amphibolite-ultramafic contact. The Study area comes to Hassan district, Random samples were collected such as Gold bearing Amphibolite schist, Amphibolite, Diorite, Gabbro through GTC (Ground Truth Check). The study carried out by Geological, Petrological, Ore microscopic, SEM-EDX and Hyperspectral signatures using advent high-tech tools of Spectro- Radiometer (Spectral Evolution SR-3500) instrument, DARWin SP.V.1.3.0 and GIS software's. The spectral signatures of the collected samples were derived in laboratory environment to achieve better accuracy. Hyperspectral (350-2500nm) were developed as works mainly on physicochemical and optical properties of the litho unit which help in mapping of gold mineralization at lithological contacts and mineralized zones of amphibolites and ultramafic rocks. The final results highlight the gold specks were noticed through ore microscopy and presence of gold is confirmed through SEM-EDX studies and also spectral characters of Gold bearing amphibolites schist and associated rocks for better mapping of Kempinakote area of Hassan district in Precambrian basement rocks and similar terrains of Dharwarcraton.
\end{abstract}

Key words: Hyperspectal signature, petrography, Ore microscopy, SEM-EDX, Gold bearing litho units, Kempinakote. 
Cite this Article: Abrar Ahmed, Maruthi N.E and H.T. Basavarajappa, Comprehensive Study of Hyperspectrl Signatures, Petrography and EDX Analysis on Gold Bearing Litho Units of Kempinakote, Nuggihalli Schist Belt, Dharwar Craton, Karnataka, India, International Journal of Computer Engineering and Technology 10(3), 2019, pp. 45-59.

http://iaeme.com/Home/issue/IJCET?Volume=10\&Issue=3

\section{INTRODUCTION}

Gold is a chemical element with the symbol Au (from Latin: aurum) and atomic number 79, making it one of the higher atomic number elements that occur naturally. In its purest form, it is a bright, slightly reddish yellow, dense, soft, malleable, and ductile metal. Lavelle (1886) first referred to the presence of very large old working in Kempinkote area, containing gold. Bruce Foote (1889) referred to the tiny outlier of the auriferous rock close to Kempinkote. Later M/s Kempinkote Gold Field Limited carried out exploratory underground development work between 1893-1896. Rama Rao (1984) recommended further detailed work. John Taylor and Sons (1965) who reviewed earlier work and carried out a spot inspection, considered this as an undoubtedly well mineralized and a promising gold prospect. During F.S. 1972-73 B.K. DhruvaRao\& T.S. Seshadri of Geological Survey of India, carried out preliminary investigation for gold in this area and suggested detailed investigation. Since 1986 GSI is carrying out detailed investigation by surface and subsurface work and delineated three prominent zones of gold mineralisation in the Kempinkote area. It is suggested that the gold mineralization is at the contact of metaultramafics and metamafics, characterized by silicification, sulphidisation and hydrothermal retrogressive alteration in the form of biotitization, chloritization and epidotization. In the Madehalli block, the northern extension area, detailed geochemical work by means of panning the heavies and counting the gold grains was carried out by GSI in 1987 and demarcated two anomaly zones. The spectral signatures of the field samples were compared with mineral spectra of USGS spectral library to record the spectral behavior (Basavarajappa and Maruthi, 2018). The absorption and reflection features are studied as described by Hunt and Salisbury (1970), Hunt et al., (1971), Hunt and Ashley (1979) and Blom et al., (1980), the fresh or weathered surface of iron metallic elements causes strong absorptions in Visible and Near Infrared region of electromagnetic wavelength (Maruthi and Basavarajappa., 2018) (Maruthi et al., 2018). A brief account of Geological, Petrological, Ore microscopy and Hyperspectral signatures studies are discussed.

\section{STUDY AREA}

The study area is located in between $12^{\circ} 54^{\prime} 0^{\prime \prime}$ ' to $12^{\circ} 55^{\prime} 0^{\prime \prime}$ ' North latitude and $76^{0} 29^{\prime} 30^{\prime \prime}$ to $76^{0} 31^{\prime} 30^{\prime}$ ' East longitude. The general elevation is of $873 \mathrm{mts}$ above MSL covering mainly red \& block soils associated with metamorphosed leucocratic gneiss, amphibolite schist, ultramafics, dolerite, gabbro, Chlorite schist and Gold bearing litho - units (CGWB, 2010). 


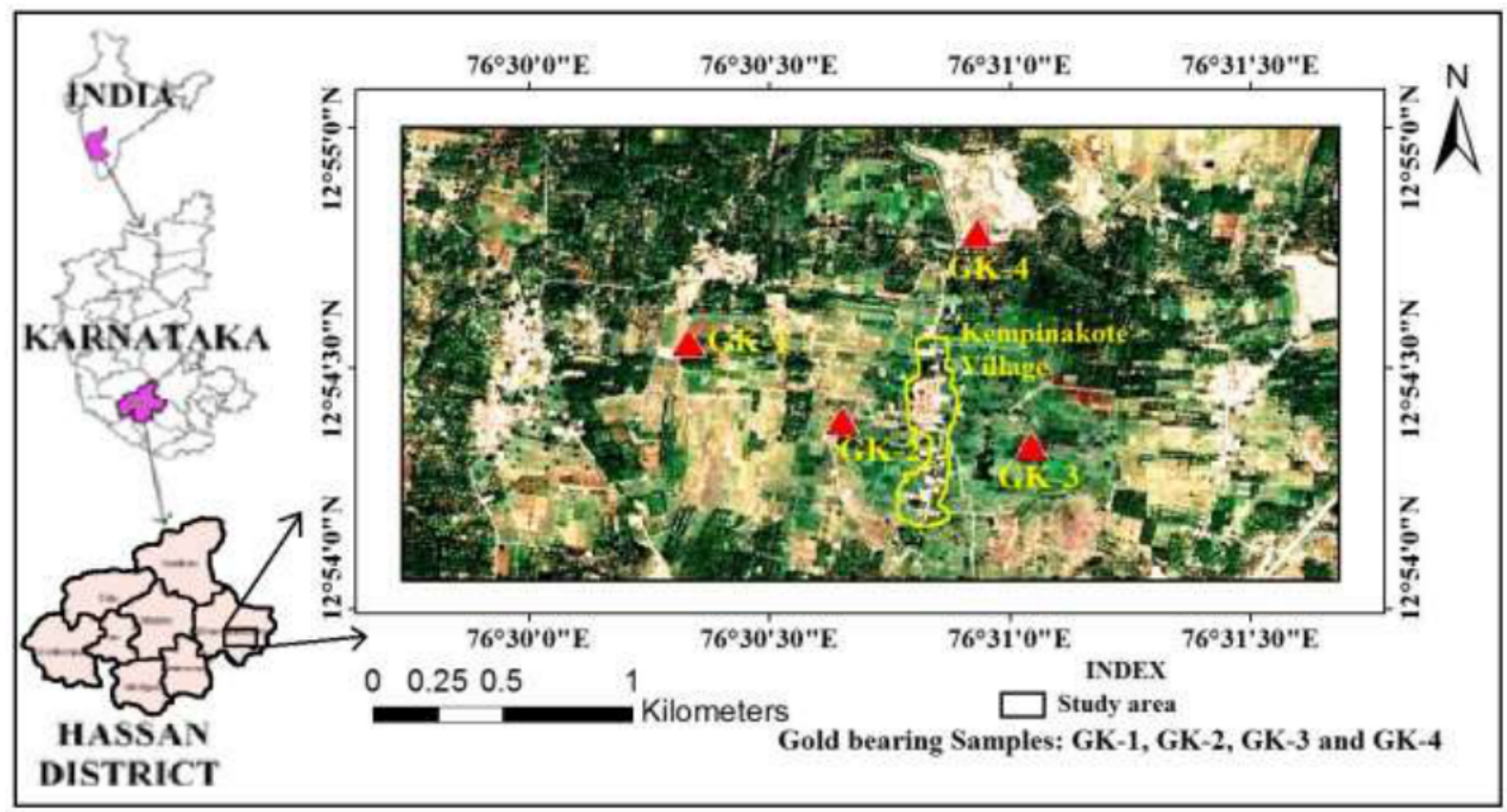

Figure 1 Google Earth image showing the location of the study area

Table 1 Sample Name and Location

\begin{tabular}{|c|l|c|c|c|}
\hline SI No & \multicolumn{1}{|c|}{ Sample Name } & Location & Latitude & Longitude \\
\hline GK- 1 & Amphibolite & Kempinakote & $12^{0} 54^{\prime} 33.8^{\prime \prime} \mathrm{N}$ & $76^{0} 30^{\prime} 20^{\prime \prime} \mathrm{E}$ \\
\hline GK- 2 & Amphibolite Schist & Kempinakote & $12^{0} 54^{\prime} 24.6^{\prime \prime} \mathrm{N}$ & $76^{0} 30^{\prime} 38.1^{\prime} \mathrm{E}$ \\
\hline GK- 3 & Gabbro & Kempinakote & $12^{0} 54^{\prime} 21.6^{\prime \prime} \mathrm{N}$ & $76^{0} 31^{\prime} 23.2{ }^{\prime} \mathrm{E}$ \\
\hline GK- 4 & Chlorite Schist & Kempinakote & $12^{0} 54^{\prime} 47.5^{\prime \prime} \mathrm{N}$ & $76^{0} 30^{\prime} 55.4^{\prime \prime} \mathrm{E}$ \\
\hline
\end{tabular}

Note: Gold atKempinakote

\section{GEOLOGY}

The Kempinakote area is situated in the southernmost tip of 55-km long NNW-SSE trending Nuggihalli schist belt. This belt is characterized by middle amphibolitefacies of metamorphic rocks. Ultramafic rocks of komatiitic affinity have also been reported from Kempinakote and other parts of Nuggihalli Schist Belt (Srikantia et al. 1985) wherein gold mineralization has been recorded. In Kempinakote most of the areas having soil cover with very few out crops of rocks are exposed in the study area. Commonly two rock types observed, Amphibolites and Ultramafics with their variants (Ramakrishnan and Vaidhyanadhan., 2008). Quartz-chlorite-biotite schist, chlorite schist, talc chlorite schist, tremolite-actinolite schist, ultramafic schist, silicified amphibolites. Due to hydrothermal activity in shears resulting in alterations, sericitisation, silicification and mineralization. These alteration zones also carry sporadic mineralization (Naqvi and Rogers, 1983; Radhakrishna and Naqvi, 1986). The topography is generally flat. Gold mineralization in general is present in sheared ultramafic rocks at the contact of amphibolites and ultramafic rocks. The surface outcrops of lithounits are very few due to predominantly soil cover in the area (Radhakrishna., 1983). Gold occurs as discrete grains along fractures in the sulphides and in quartz gangue and appears to be of free milling type. The mineralization is lithological as well as sheared 
controlled (Swaminath and Ramakrishnan, 1981). Gold occurs near Kempinkote at the southern end of the Nuggihalli schist belt at the contact between ultrabasics and amphibolites and the gold mineralisation is confined to a silicified zone.

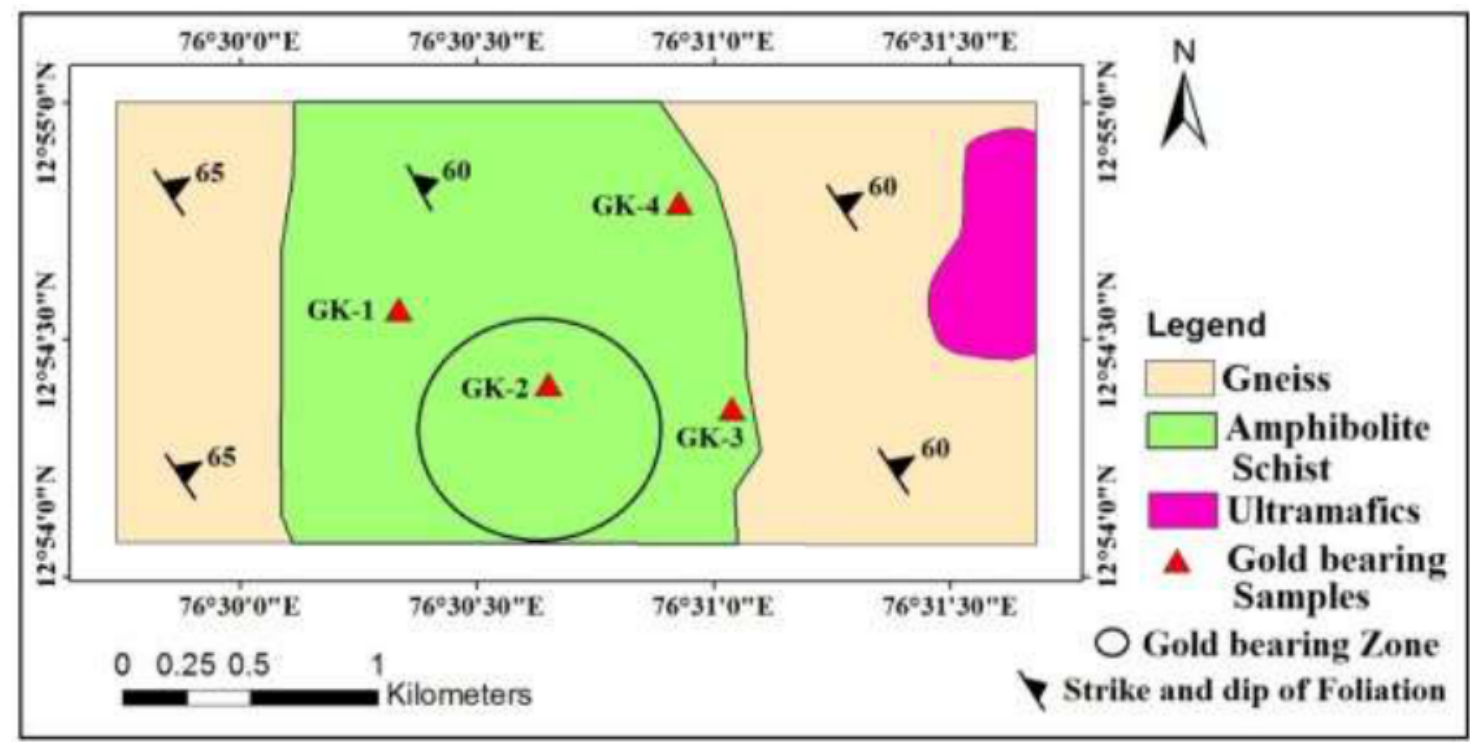

Figure 2 Geological map of the study area with sample Locations (after GSI 1965)

\section{METHODOLOGY}

Field based samples were collected and carried carefully to the laboratory for Petrographic study using Petrological, Mineralogical research Microscope; Samples were studied under transmitted light microscope, Stereo zoom microscope, Scanning electron Microscope with electron dispersive spectroscopy (SEM-EDS) at Central instrumentation and research facility Vijnana Bhavan University of Mysore; Hyperspectral signatures analyses for all samples were carried out using Lab Spectro-radiometer instrument (Spectral Evolution SR-3500) at Department of Earth Science University of Mysore, Manasagangothri, Mysuru. DARWin SP.V.1.3.0 software is well utilized in analyzing each spectral curves obtained from the collected samples (average of 4 spectral curves from each samples) and well correlated with the standard curves of USGS, JPL and JHU. Survey of India (GSI) topo map and Geological quadrangle map (57d) of 1:2.50.000 scale is used during the field work to study Gold bearing litho units Basavarajappa et al., 2018. Garmin-72 GPS is used to record the exact locations of each sample with an error of 9 mts during field visits.

\section{PETROGRAPHY}

\subsection{Amphibolite}

The Amphibolite optical properties show it is strongly green in colour, yellow-blue, bluegreen and brown. It shows strong pleochroic, moderate relief, high cleavage, birefringence biaxial and pleochroic appears in various shades of green and brown. In plane polarized light, the mineral colour of amphibole ranges from yellowish green to dark green in Colour (Fig.3) 
Comprehensive Study of Hyperspectrl Signatures, Petrography and Edx Analysis on Gold Bearing Litho Units of Kempinakote, Nuggihalli Schist Belt, Dharwar Craton, Karnataka, India
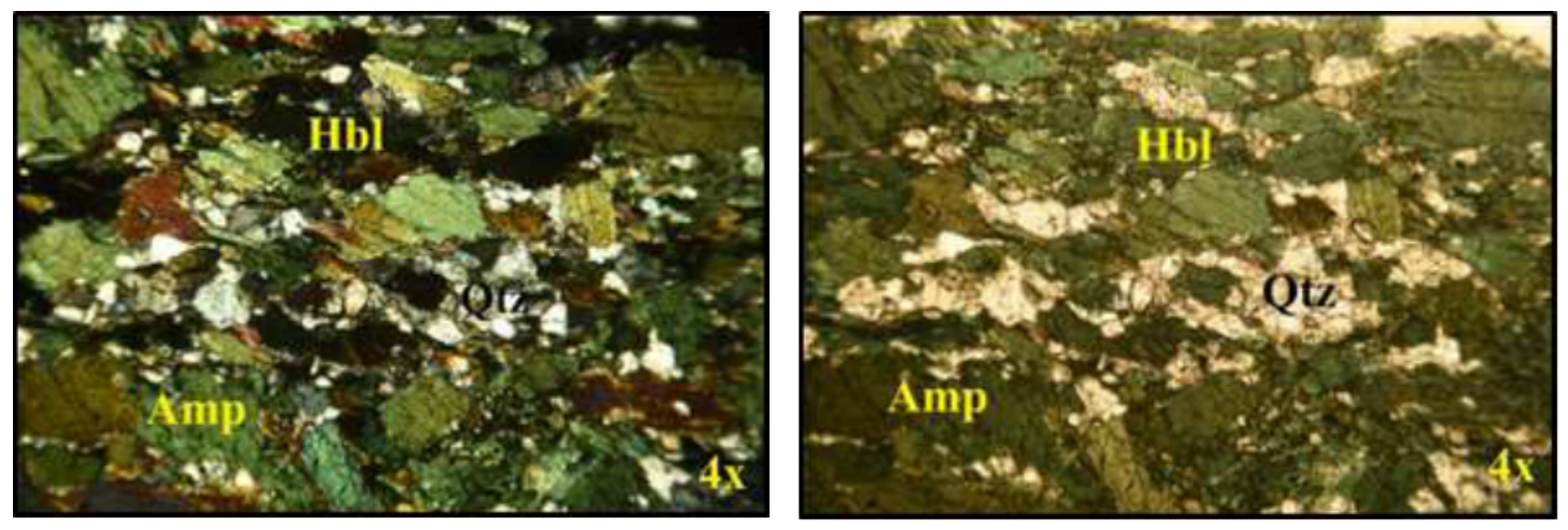

Figure 3 Photomicrographs of Amphibolite under PPL and XPL.

\subsection{Amphibolite Schist}

Actinolite is a hydrous calcium, magnesium and iron silicate. Color shows pale green, pleochroic from green to greenish yellow. The rest of the properties regarding from, cleavage, birefringence, sigh of elongation and extinction are the same as in tremolite it has slightly higher relief than tremolite. Distinguishing features, low extinction angle pleochroism and the amphibole cross sections are characteristic. It is distinguished from hornblende by its lower extinction angles and from aegirine by its higher extinction angles and amphibole cross sections and from aegirineaugite by its lower extinction angles and amphibole cross sections. Amphibole is usually strongly green in coloure, yellow-blue, blue-green and brown. It shows strong pleochroic, moderate relief, high cleavage, birefringence biaxial and pleochroic appears in various shades of green and brown. In plane polarized light, the mineral colour of amphibole ranges from yellowish green to dark green in Colour(Fig.4).
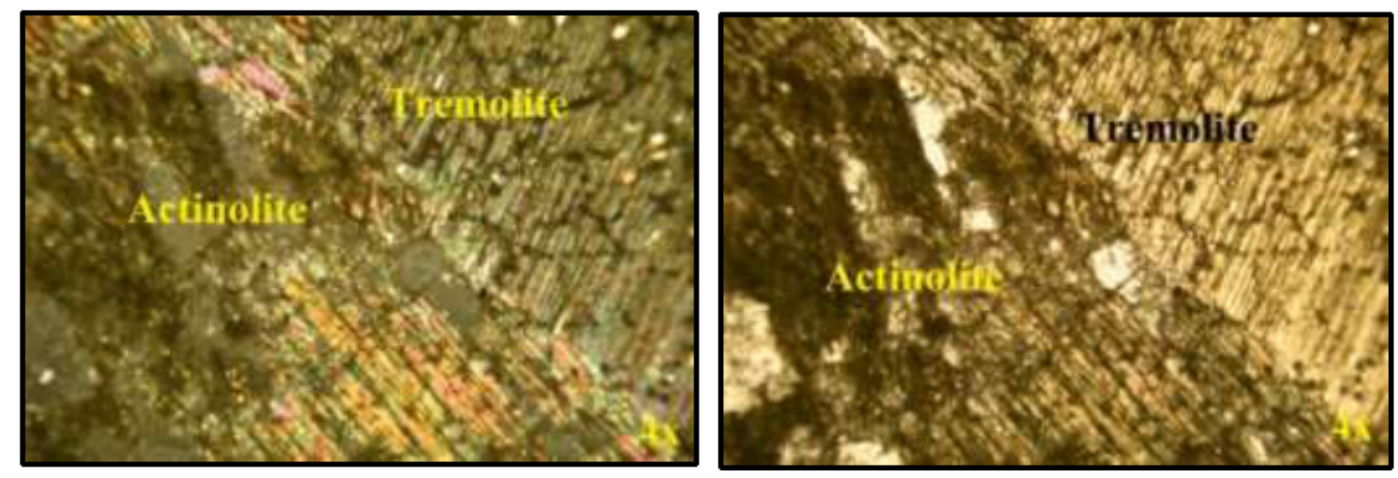

Figure 4. Photomicrographs of Amphibolite schist under PPL and XPL

\subsection{Gabbro}

Hypersthene is a iron magnesium silicate with more than $15 \% \mathrm{FeSio}_{3},(\mathrm{Mg}, \mathrm{Fe}) \mathrm{Sio}_{3} \mathrm{Color}$ : body colour more marked than in enstatite, colorless to pale green or pale red. Form usually as prismatic grains the cross sections are nearly square. Well-developed one set of cleavage traces in prismatic grains and two sets of cleavage traces at right angles to each other in ( cross section) grains having nearly square shape. Relief high. Birefringence weak ( slightly stronger than in enstatite) yellow to red of the I order interference colors positive elongation, biaxial negative. Extinction parallel in most of the mineral sections.Hornblende is the commonest amphibole found in igneous rocks and is most abundant in acid and intermediate rocks. It is less common in ultrabasic and basic rocks where other amphiboles are more 
commonly observed. Hornblende often alters to an intergrowth of tremolite and actinolite sometimes with epidote, giving a blue-green appearance in hand specimen (Fig.5).
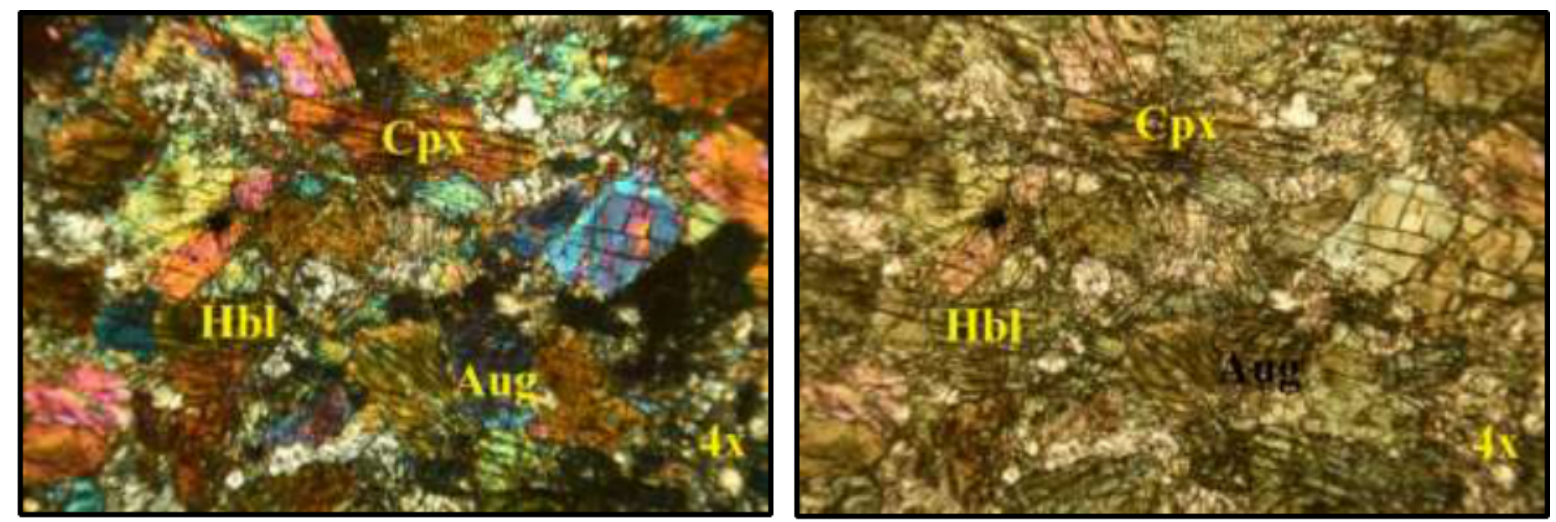

Figure 5 Photomicrographs of Gabbro under PPL and XPL

\subsection{Chlorite Schist}

The mineral chlorite is a hydrous silicate of aluminium, iron and magnesium optical properties shows colourless or pale green to deep green faintly to moderately pleochroic in shades of green and yellow. Prominent cleavage traces parallel to the length; birefringence is weak; extinction parallel to the cleavage trace are observed in most of the chlorite minerals and crystal system is monoclinic. Tremolite is a mineral that is typically associated with secondary alteration processes in igneous rocks as well as in metamorphic rocks in the form of typical mineral facies of green schists. It occurs as a result of alteration of micas, although it is commonly found as alteration of amphiboles and pyroxenes. The pleochroic property shows light green to colorless; while medium relief interference color shows berlin blue color. The second order interference color is depicted by the mineral mica (Fig.6).
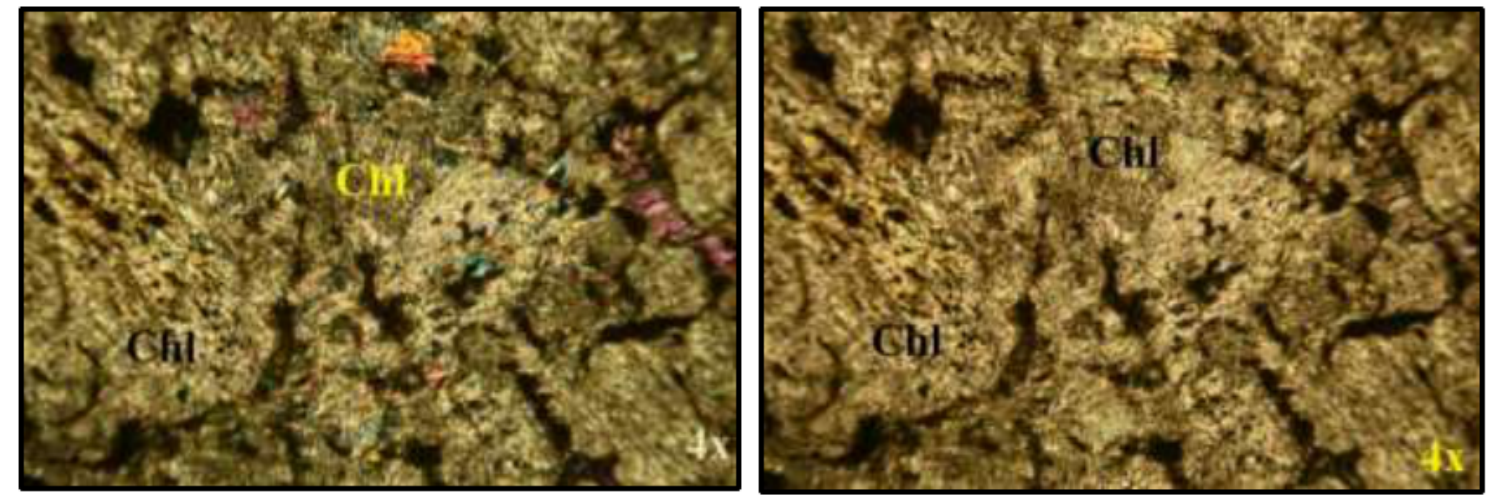

Figure 6 Photomicrographs of Chlorite schist under PPL and XPL.

\section{ORE MICROSCOPIC STUDY}

The ore microscope is the basic instrument for the petrographic examination of the large and economically important group of minerals referred to collectively as "ore" or "opaque" minerals. Although neither term is strictly correct both terms are frequently used synonymously. The ore microscope is similar to conventional petrographic microscopes in the systems of lenses, polarizer, analyzer, and various diaphragms employed, but differ in that its primary method of illumination is a light source above the sample to allow examination by light reflected from polished surfaces (Siddaraju et al., 2019). The increasing interest in oregangue relationships and the recognition that much textural information can be derived from the examination of translucent ore minerals in polished thin sections now commonly leads to 
the use of microscopes equipped for both reflected- and transmitted-light study (James and David., 1940). The preparation of polished surfaces free from scratches, from thermal and mechanical modification of the sample surface, and from relief is essential for the examination, identification, and textural interpretation of ore minerals using the reflected-light microscope. Adequate polished surfaces can be prepared on many types of materials with relatively little effort using a wide variety of mechanical and manual procedures (Siddaraju et al., 2019). However, ore samples often present problems because they may consist of soft, malleable sulfides or even native metals intimately intergrown with hard, and sometimes brittle, silicates, carbonates, oxides, or other sulfides. Weathering may complicate the problem by removing cements and interstitial minerals and by leaving samples that are friable or porous. Delicate vug fillings also cause problems with their open void spaces and poorly supported crystals. Alloys and beneficiation products present their own difficulties because of the presence of admixed phases of variable properties and fine grain sizes (James and David., 1940).
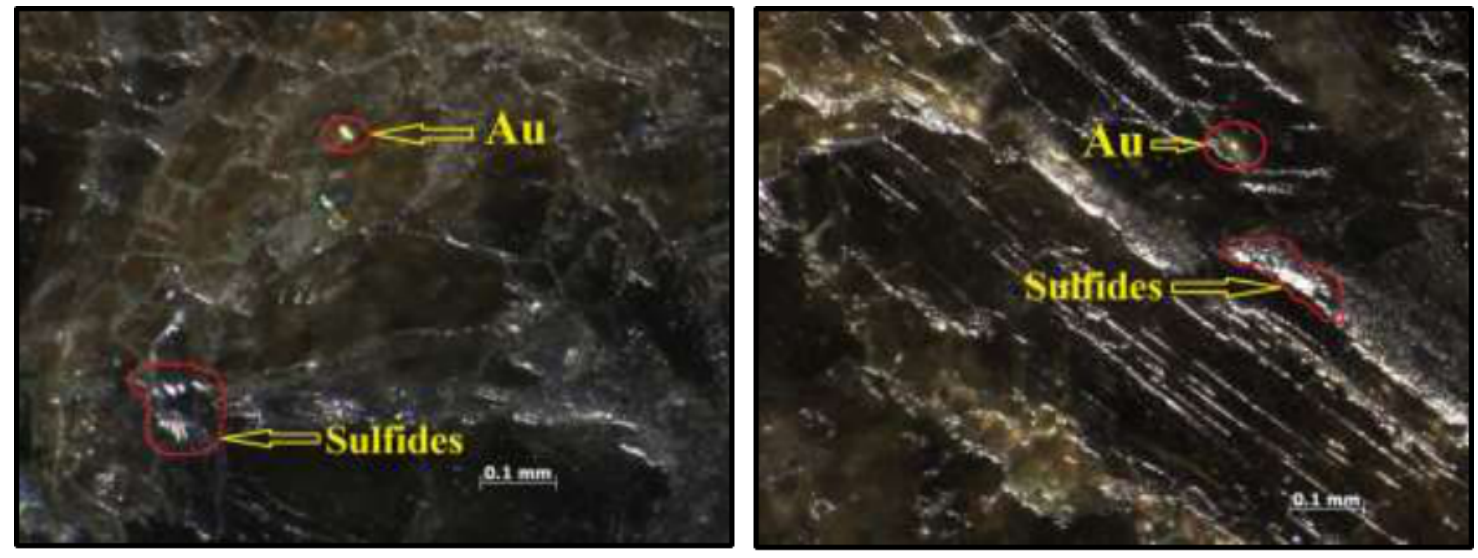

Figure 7 Ore Microscope photos shows Gold associated with Amphibolite schist.

Ore petrographic studies reveal a fairly consistent mineral assemblage of ore minerals like gold, pyrite, Chalcopyrite, Bismuth, Sphalerite and Magnetite. Gold Under microscope, it shows yellow color, very strong internal reflection white with yellowish tint with marked variable extinction. It shows characteristic extremely strong bireflectance, parallel displacement is very common, often produce twinning like texture. The polysynthetic twinning is indicated by marked variation in polarization effects in sections (Fig.7). Small speck of gold grains and sulfides occur as fine to medium anhedral to subhedral grains and as fillings mostly aligned along the schistosity observed with minor amount. Gold is bright yellowish in color showing high reflectance and actinolite is the dominant mineral in the rock (Fig.7).

\section{SEM AND EDS/EDX}

Scanning Electron Microscopy (SEM) magnifies a specific sample region using a high energy focused beam of electrons. The sample is under vacuum to ensure the electron beam stays focused and does not interact with particles in the air. When the beam of electrons hits the sample, it causes secondary electrons to be released from the sample which are detected to provide an image based off the topography of the surface. The two detectors most commonly used include the Secondary Electron Detector (SED) and the Backscattered Electron (BSE) Detector. The electrons interact with the detector to create an image. SEM Analysis is more powerful than Optical Microscopy not only because of the much increased magnification power but also because of the increase in depth of field (Siddaraju et al., 2019). The sample 
region evaluated with SEM Analysis can also be analyzed to determine the specific elements that comprise the sample region by utilizing Energy Dispersion Spectroscopy (EDS). X-rays are also released from the surface of the sample that carries a unique energy signature that is specific to elements found in the sample. These X-rays are detected with the EDS detector to give elemental information about the sample. EDS provides data about the chemical composition of the sample and provides additional data about the features that are observed in the SEM micrographs. This combined technique is referred to as SEM-EDS or SEM-EDX Analysis (Pinaki Sengupta et al., 2008).

Major element composition of samples of Gold bearing Amphibolite schist were determined at the petrography, Ore microscopic study and Hyperspectral method. SEM-EDS Analysis is a great method for determining particle sizes and elemental composition. It is also a go-to analytical technique for performing Nano characterization. SEM analysis can be performed as part of a film layer analysis to determine the thickness of a film. Not only that, used in conjunction with EDS it is possible to compare different chemical compositions between each layer. The topography of films can at times mask the number of film layers in a sample (Santos and Brandno, 2005).
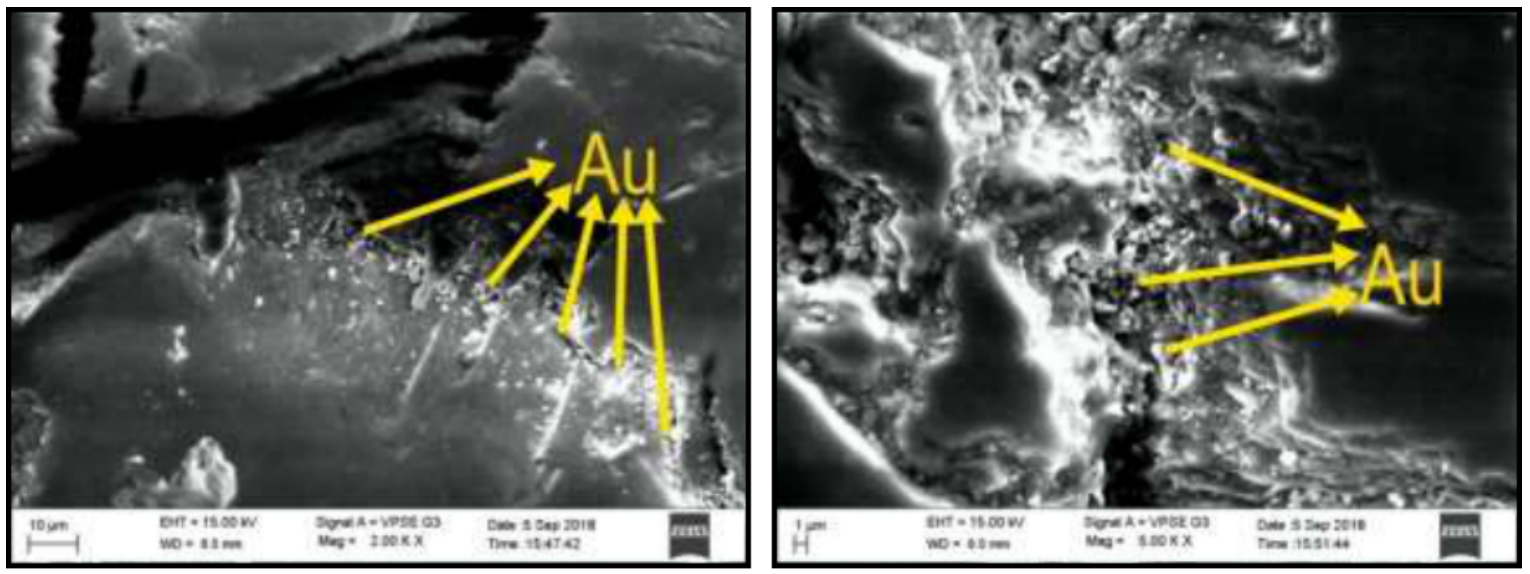

Figure 8. SEM image data of Gold mineralization within amphibolite schist

The resulting surface morphology was observed using a Hitachi S-3400N Scanning Electron Microscope with energy of $5.00 \mathrm{kV}$ model EVO LS15. In this work, shows presence of Gold element (Fig.8). Energy Dispersive X-ray Spectroscopy (EDS) as an analysis method, Gold and sulfides show EDS lines at similar energies detect the chemical composition of $\mathrm{Au}$, $\mathrm{C}, \mathrm{O}, \mathrm{Mg}, \mathrm{Al}, \mathrm{Si}, \mathrm{Cr}$ and $\mathrm{Fe}$ were determined. Here mainly concentrate of gold presence is in $0.12 \%$ and atomic $0.01 \%$ (Fig.9) (Table.2). The EDS technique detects X-rays emitted from the sample during bombardment by an electron beam to characterize the elemental composition of the analyzed volume. Features or phases as small as $1 \mu \mathrm{m}$ or less can be analyzed. keep the electron beam stationary on a spot or series of spots and generate spectra that will provide more localized elemental information, have the electron beam follow a line drawn on the Gold bearing sample image and generate a plot of the relative proportions of previously identified elements along that spatial gradient, defined elements over the scanned area identify the elements of $\mathrm{Au}, \mathrm{C}, \mathrm{O}, \mathrm{Mg}, \mathrm{Al}, \mathrm{Si}, \mathrm{Cr}$ and Fe here mainly concentrate the Gold presence in $0.12 \%$ and atomic $0.01 \%$. Presence of Gold in Amphibolite bearing schistose rock is confirmed by using EDS / EDX studies. (Fig.9)(Table.2). 
Comprehensive Study of Hyperspectrl Signatures, Petrography and Edx Analysis on Gold Bearing Litho Units of Kempinakote, Nuggihalli Schist Belt, Dharwar Craton, Karnataka, India

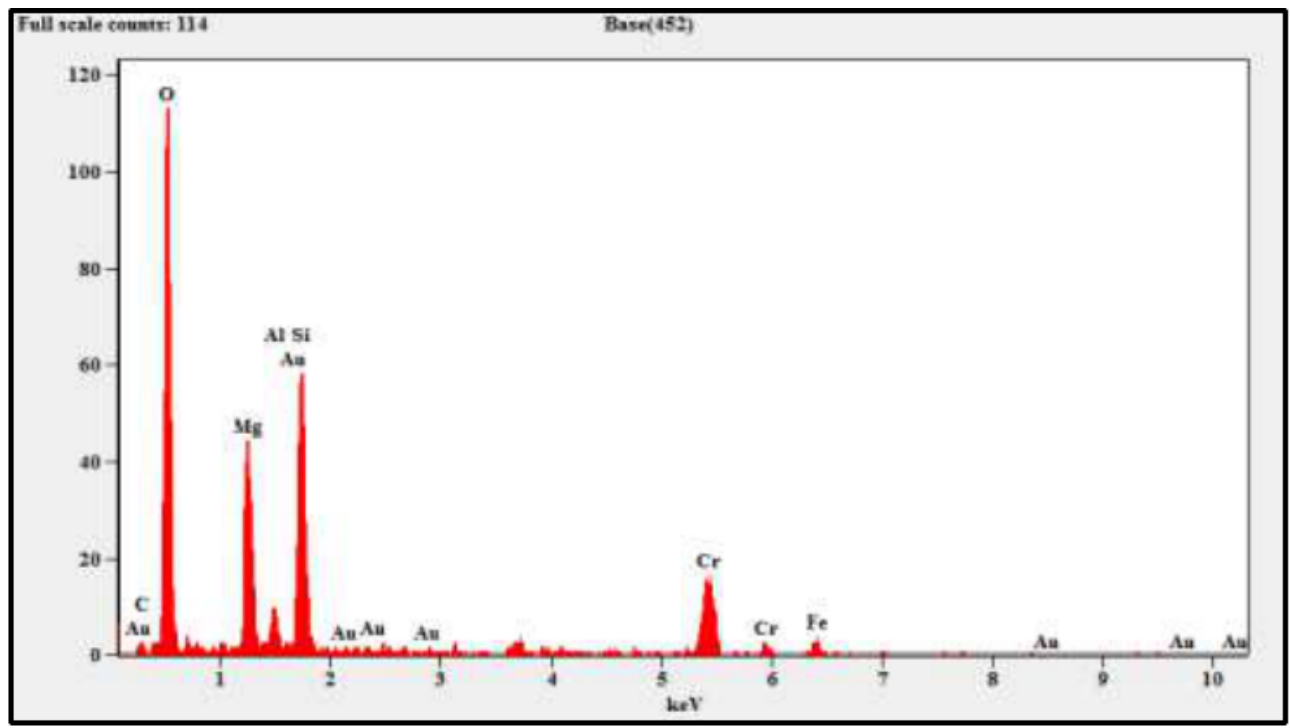

Figure 9 Typical EDX spectrum: $y$-axis depicts the number of counts and $x$-axis the energy of the $\mathrm{X}$-rays. The position of the peaks leads to the identification of the elements and the peak height helps in the quantification of each element's concentration in the sample.

Table 2. Phase fractions (wt $\%)$ measured by SEM and EDS image

\begin{tabular}{|c|c|c|c|}
\hline $\begin{array}{c}\text { Element } \\
\text { Line }\end{array}$ & Weight \% & $\begin{array}{c}\text { Weight \% } \\
\text { Error }\end{array}$ & Atom \% \\
\hline $\mathrm{C} \mathrm{K}$ & 11.74 & \pm 1.90 & 18.27 \\
\hline $\mathrm{O} \mathrm{K}$ & 53.08 & \pm 1.43 & 62.00 \\
\hline $\mathrm{Mg} \mathrm{K}$ & 8.65 & \pm 0.68 & 6.65 \\
\hline $\mathrm{Al} \mathrm{K}$ & 1.46 & \pm 0.36 & 1.01 \\
\hline $\mathrm{Si} \mathrm{K}$ & 10.40 & \pm 0.64 & 6.92 \\
\hline $\mathrm{Cr} \mathrm{K}$ & 11.04 & \pm 1.23 & 3.97 \\
\hline $\mathrm{Fe} \mathrm{K}$ & 3.53 & \pm 0.80 & 1.18 \\
\hline $\mathrm{Au} \mathrm{M}$ & 0.12 & \pm 0.49 & 0.01 \\
\hline Total & 100.00 & & 100.00 \\
\hline
\end{tabular}

\section{HYPERSPECTRAL SIGNATURS}

Spectral signature measures all types of wavelengths that reflect, absorb, transmit and emit electromagnetic energy from the objects of the earth surface (Ali M. Qaid et al., 2009) (Basavarajappa et al., 2018). Specral Evolution (SR-3500) Spectro-radiometer instrument has the ability to measure the spectral signatures of different rocks/ minerals. The SR-3500 operate in the wavelength range of 350-2500 nm with three detector elements: a 512-element Si PDA (Photo Diode Array) covering the visible range and part of the near infrared (up to $1000 \mathrm{~nm}$ ) and two 256-element InGaAs arrays extending detection to $2500 \mathrm{~nm}$. The spectral signatures of the representative samples were compared with mineral spectra of USGS spectral library in DARWin SP.V.1.3.0 (Hunt et al., 1971). Absorption spectral values obtained from the DARWinsoftware lab Spectra is the one character helps in the study of major and minor mineral constituents (Maruthi et al., 2019).

\section{RESULT AND DISCUSSION}

Major element composition of samples of Gold bearing rocks were determined at the chemical division, ore microscope study, SEM-EDS study and petrography its using 
analytical methods. Gold bearing rocks were determined at the using spectral signatures. The spectrometer component is a crossed Czerny-Turner configuration using ruled gratings as the dispersive elements. Energy enters the spectrometer and is collimated before being reflected off the gratings and refocused onto the PDA (Photo Diode Array) detectors. There are three detectors. The first is a 512-element silicon array covering the spectral range from 350 to $1000 \mathrm{~nm}(280-1000 \mathrm{~nm})$. Two thermoelectrically cooled InGaAs (Indium Gallium Arsenide) arrays of 256 elements each extend the spectral range up to $1900 \mathrm{~nm}$ and $2500 \mathrm{~nm}$ respectively. The spectroradiometer and controlling electronics are contained in the housing. International standards for minerals such as USGS were compared along with the major elements for the field samples to check precision and accuracy of measurement. The certified and analyzed values of USGS are given in the figures along with major element abundances of samples to check the error limits of measurement (Hunt et al., 1971).

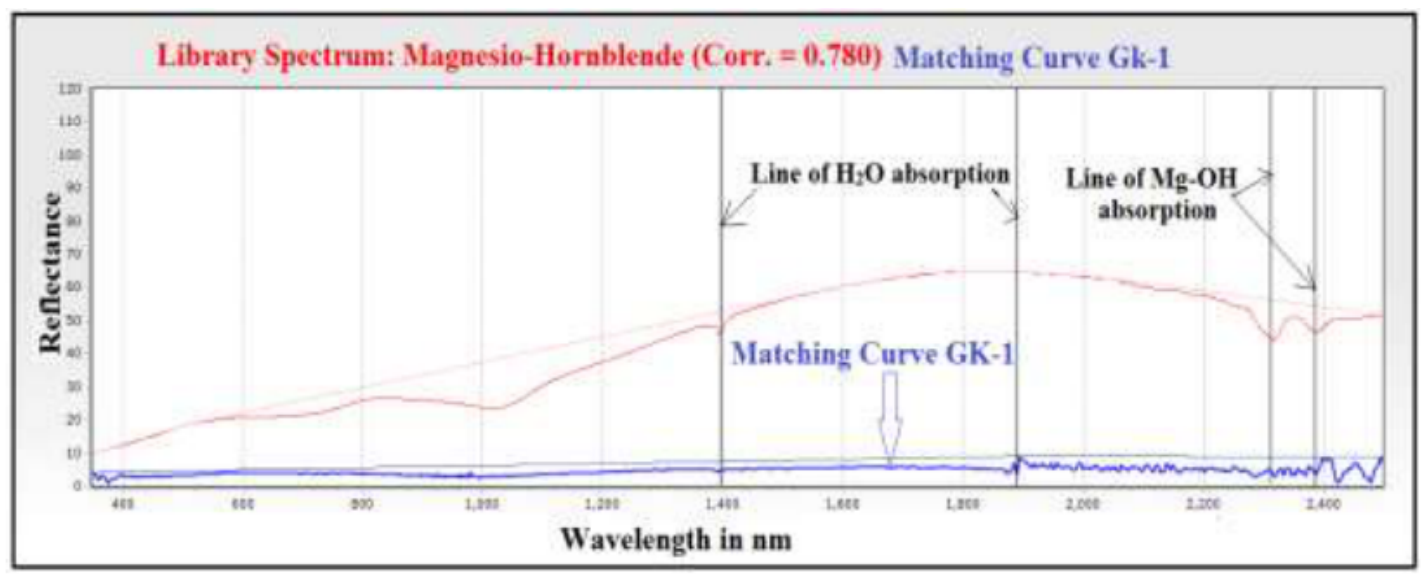

Figure 10. Lab Spectral signatures of Magnesio-Hornblende, Kempinkote area

Hyperspectral signatures hornblende shows intense absorption feature in $2.40 \mu \mathrm{m}$ of the electromagnetic spectrum (Hunt et al., 1971). Absorption anomalies at $0.55 \mu \mathrm{m}$ and $0.9 \mu \mathrm{m}$ are observed due to the presence of $\mathrm{Fe}^{3+}$ and $\mathrm{Fe}^{2+}$ ions respectively (Fig.10). The element content of hornblende shows $\mathrm{SiO}_{2}$ ranging between $46.71 \%$ and $47.48 \%$; $\mathrm{MgO}$ content is fairly moderate and ranges from $9.87 \%$ to $10.77 \%, \mathrm{Al}_{2} \mathrm{O}_{3}$ content low ranges from $4.99 \%$ to $3.29 \%$; $\mathrm{CaO}$ content is $11.09 \%$ to $10.09 \%$; $\mathrm{TiO}_{2}$ content is fairly low and varies from $1.21 \%$ to $1.3 \% ; \mathrm{P}_{2} \mathrm{O}_{5}$ ranges from $0.04 \%$ to $0.05 \%$ and $\mathrm{K}_{2} \mathrm{O}$ content of $1.91 \%$ to $1.63 \%$.). Library spectrums Magnesio - Hornblende correlation score 0.780 percent match the curve (Fig.10). Lab spectra of Amphibolite strong absorption range identified in the wavelength of $2.30 \mu \mathrm{m}$ and $2.40 \mu \mathrm{m}$ (Fig.10).

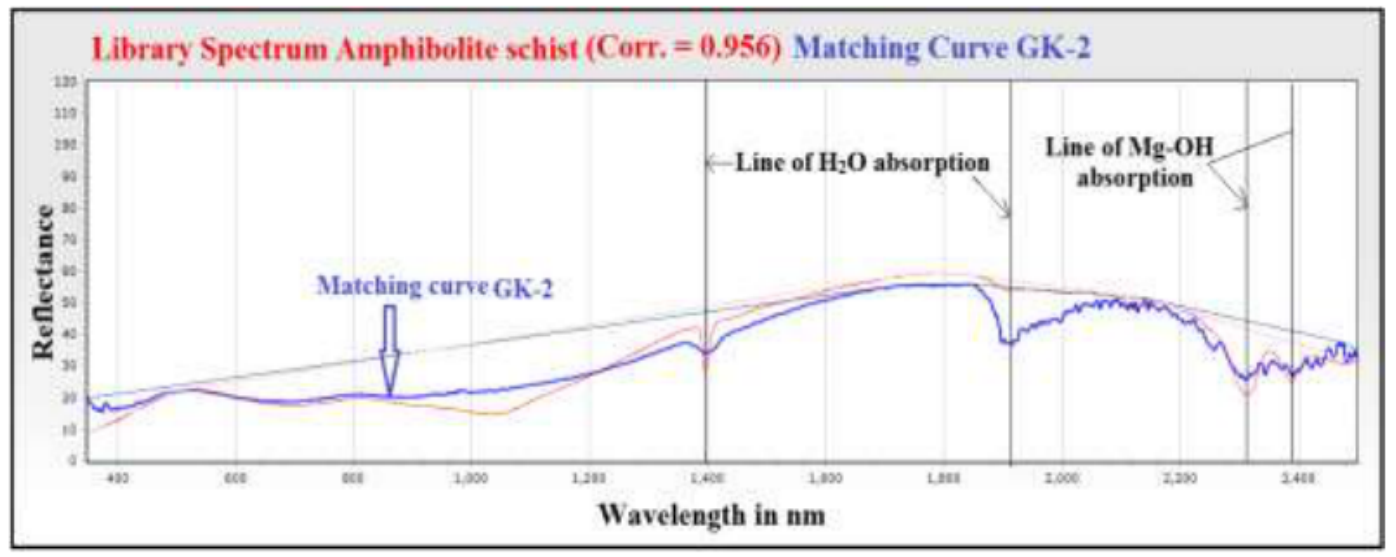

Figure 11. Lab Spectral signatures of Amphibolite Schist, Kempinkote area 
Comprehensive Study of Hyperspectrl Signatures, Petrography and Edx Analysis on Gold Bearing Litho Units of Kempinakote, Nuggihalli Schist Belt, Dharwar Craton, Karnataka, India

Mixture Actinolite-Tremolite, Phlogopite and Chlorite Hornfels Rock (Amphibole group) $\mathrm{Ca}_{2}\left(\mathrm{Mg}, \mathrm{Fe}^{+2}\right)_{5} \mathrm{Si}_{8} \mathrm{O}_{22}(\mathrm{OH})_{2}$ Actinolite, Tremolite bearing rock contact skarn quartzmonzonite wall rocks with the iron ore deposit Spectral discussion generic broad $\mathrm{Fe}^{2+}$ one micron band an $\mathrm{OH}$ stretch at 1.4 microns and strong $(\mathrm{Mg}, \mathrm{Fe}) \mathrm{OH}$ combination bands at 2.32 and 2.38 microns.forms series with tremolite and Ferro-actinolite. Unusually large number of sharp reflections indicating excellent crystallinity and suggesting compositional homogeneity pattern is creel califomia and calculated tremolite pattern of Brog and Smith (1969). Chemical compostion of Actinolite - Tremolite Schist shows the distribution of major element content as $\mathrm{SiO}_{2}-56.72 \%, \mathrm{Al}_{2} \mathrm{O}_{3}-1.28 \%$, minor content as $\mathrm{TiO}_{2}-0.02 \%, \mathrm{Cr}_{2} \mathrm{O}_{3}-0.01 \%, \mathrm{FeO}-2.37 \%$, $\mathrm{MnO}-0.38 \%, \mathrm{MgO}-25.58 \%, \mathrm{CaO}-14.27 \%, \mathrm{Na}_{2} \mathrm{O}-0.27 \%, \mathrm{~K}_{2} \mathrm{O}-0.03 \%$. Library spectrum Gold bearing Amphibolite schist correlation score 0.956percent match the curve (Fig-11)

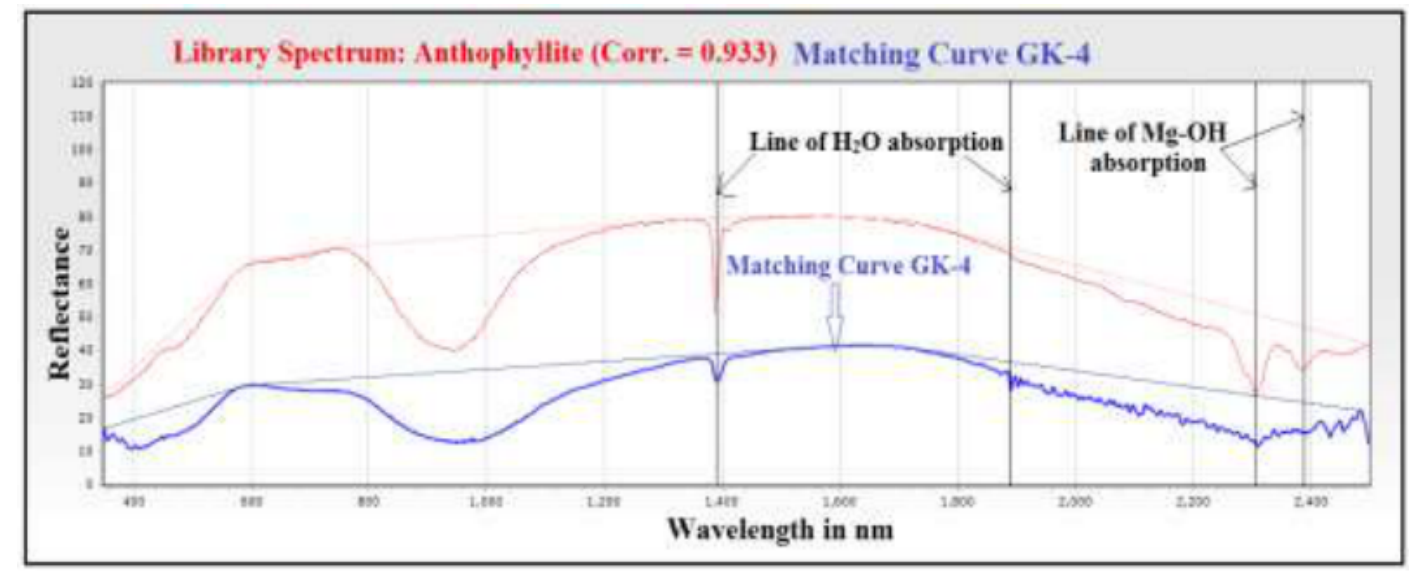

Figure 12. Lab Spectral signatures of Anthophyllite, Kempinkote area

Spectral signatures find the graph showing $\mathrm{H}_{2} \mathrm{O}$ content $\mathrm{Ca}$ and $\mathrm{Fe}, \mathrm{Mg}, \mathrm{OH}$ minerals presence in the Sample. Amphiboles are found principally in metamorphic and originally in igneous form. They occur in many metamorphic rocks, especially those derived from mafic igneous rocks (those containing dark-coloured ferromagnesian minerals) and siliceous dolomites.Major and minor element content of Chlorite schist shows $\mathrm{SiO}_{2}$ ranging 6.20\%; $\mathrm{MgO}$ content is fairly low and ranges from $21.42 \%$ to $26.41 \% ; \mathrm{Al}_{2} \mathrm{O}_{3}$ content high ranges $5.2 \%$. $\mathrm{CaO}$ content is $12.57 \% ; \mathrm{K}_{2} \mathrm{O}$ content of ranges from $0.10 \%$ to $0.62 \%$; $\mathrm{TiO}_{2}$ content is fairly low and varies from $0.11 \%$ to $0.61 \%$ and $\mathrm{P}_{2} \mathrm{O}_{5}$ ranges from $0.12 \%$ to $0.41 \%$ (M. Qasim Jan 1988). Spectal discussion Sample plots provide strong absorption range from $2.3-2.4 \mu \mathrm{m}$ representing the mineral amphibole shows intense absorption feature in $2.35 \mu \mathrm{m}$ of the electromagnetic spectrum (Hunt et al., 1971). Absorption anomalies at wavelength regions $0.55 \mu \mathrm{m}$ and $0.9 \mu \mathrm{m}$ of $\mathrm{Fe}^{3+}$ and $\mathrm{Fe}^{2+}$ ions are observed respectively (Fig.12). Absorption range $1.4 \mu \mathrm{m}$ and $1.9 \mu \mathrm{m}$ is noticed due to the presence of water and hydroxyl molecules in the present sample (Ali M.Qaid et al., 2009). Library spectrums Gold bearing Chlorite Schist correlation score 0.933 percent match the curve (Fig.11). 

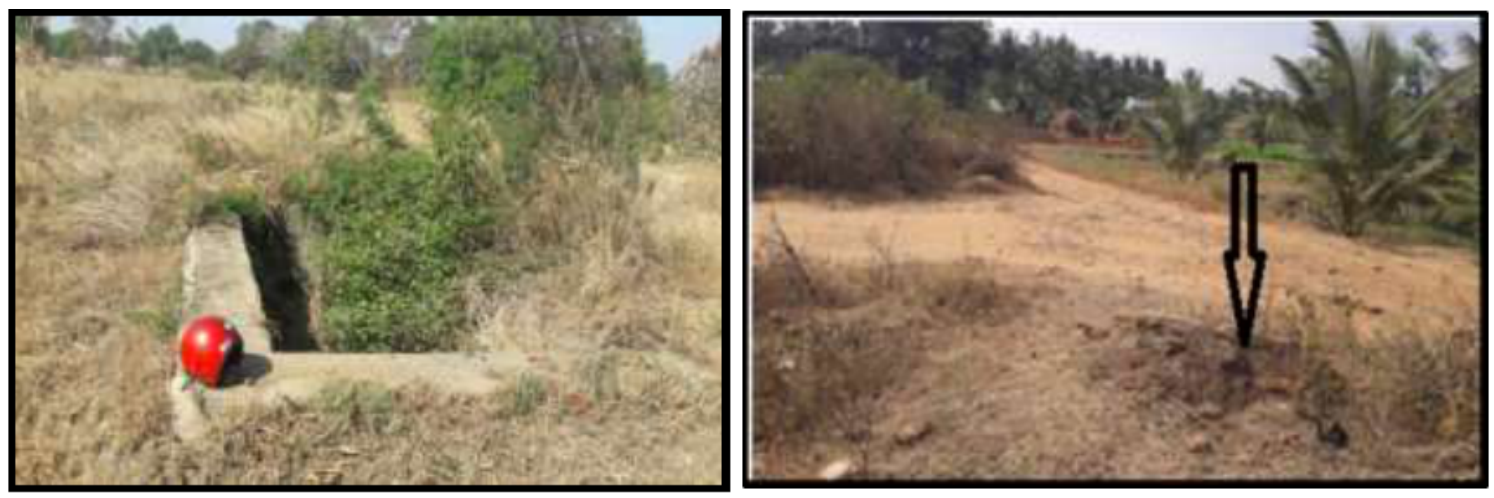

Figure 13. Ancient Gold shaft of Kempinakote area Hassan district.

\section{CONCLUSION}

Hyperspecral signatures, optical properties, Ore microscopic study, SEM-EDS analysis, and Arc GIS software's helps to find out Geological, Petrographic, Physical and Chemical characteristics and discrimination shows purity of the Gold mineral present in the Precambrian rock. Analyzed and Studies for the selected samples were carried out and identified mineral assemblage of Gold bearing rocks. Ore microscopic study the perfect texture and yellow to pale yellow character reveal the presence of Gold mineral present in the collected samples. Lab spectra of Gold bearing Amphibolite and Chlrite Schist identified in the wavelength of $2.25 \mu \mathrm{m}$ and $2.40 \mu \mathrm{m}$ regions through the absorption curve matches the USGS standard shows the purity of mineral present in the rock. Hyperspectral signature data were analyzed for the same part of Gold bearing sample using Lab Spectro-radiometer which shows best match with that of USGS Spectral Library Standards Spectral Evolution (SR3500) instrument. Including the all methods are proved the Gold mineralization in the Amphibolite schists derived from the deep seated/ ultramafic magma and due to Hydrothermal alterations of Gold mineralization in the study area.

\section{ACKNOWLEDGMENT}

The authors are indepthly acknowledged Prof. M.S. Sethumadhav, Chairman, DoS in Earth Science, Centre for Advanced Studies in Precambrian Geology (CAS), Manasagangothri, University of Mysore, Mysuru.

\section{REFFERENCES}

[1] Ali M. Qaid, Basavarajappa H.T. and Rajendran S. (2009). Integration of VNIR and SWIR Spectral Reflectance for Mapping Mineral Resources; A case study, North East of Hajjah, Yemen, J. Indian. Soc. Remote Sens, Vol.37, Pp: 305-315.

[2] B.P.RadhakrishnaAndL.C.Curtis (1999). Gold In India, Geological Society Of India, Banglore, Pp-1 To Pp-55.

[3] Basavarajappa H.T and Maruthi N.E (2018). Hyperspectral And Petro - Chemical Signatures Study On Shear Zone Controlled Corundum Bearing Pelitic Rocks Of Budipadaga Area, Chamarajanagara District, Karnataka, India. International Journal of Research and analytical Reviews (IJRAR) Volume 5, Issue 3, pp. 906-913.

[4] Basavarajappa H.T and Maruthi N.E (2018). Hyperspectral and Petro - Chemical Signatures study on Corundum Bearing Litho-Units around Sringeri Area, Chikmagalur District, Karnataka, India. RESEARCH REVIEW International Journal of Multidisciplinary Volume 3, Issue10, pp. 899-904. 
Comprehensive Study of Hyperspectrl Signatures, Petrography and Edx Analysis on Gold Bearing Litho Units of Kempinakote, Nuggihalli Schist Belt, Dharwar Craton, Karnataka, India

[5] Basavarajappa H.T and Maruthi N.E (2018).Petro - Chemical And Spectral Signatures On Corundum Bearing Precambrian Amphibolites In Sullia Area, Dakshina Kannada District, Karnataka, India. Journal of Emerging Technologies and Innovative Research (JETIR) Volume 5, Issue 7, pp. 75-83.

[6] Basavarajappa H.T and Maruthi N.E (2018). Petrochemical characteristics and Hyperspectral signatures on Corundum bearing Precambrian litho-units of Varuna area, Mysuru district, Karnataka, India. International Journal of Creative Research Thoughts, Volume6, Issue1, Pp.998-109.

[7] BasavarajappaH.T, and Maruthi N.E (2018). Hyperspectral Signature Study Finds Corundum Alters To DiasporeInflueance Of Climate Change Of DharwarCratonArsikere Band Of Haranahalli, Hassan District, Karnataka, India. Journal of Environmental Science, Computer Science and Engineering and Technology (JECET) Volume 7, Issue 2, Pp.238-246.

[8] Basavarajappa H.T, Maruthi N.E and Manjunatha M.C (2017). Hyperspectral Signatures and Field Petrography of Corundum bearing litho-units in Arsikere band of Haranahalli, Hassan District, Karnataka, India. International Journal of Creative Research Thoughts, Volume5, Issue4, Pp.3791-3798.

[9] Basavarajappa H.T, Maruthi N.E, Jeevan L and Manjunatha M.C (2018). Physicochemical charectristics and hyperspectral signature study using geomatics on gem verity of corundum bearing precambrianlitho-units of Mavinahalli area, Mysuru district, Karnataka, India. International Journal of Computer Engineering and Technology(IJCET) Volume 9, Issue 1, pp. 102-112.

[10] Bruce Foote, R. (1887). Auriferous tracts in Mysore, Mysore Gazetteer, Vol-I, Editor: Lowis Rile

[11] Chadwick, B., Ramakrishnan, M. and Viswanatha, M.N. (1981). Structural and metamorphic relations between Sargur and Dharwarsupracrustal rocks and Peninsular Gneiss in Central Karnataka, Jou. Geol. Soc. Ind., 22, pp. 557-569.

[12] Chadwick, B., Ramakrishnan, M., Viswanatha, M.N. and Srinivasa Murthy, V. (1978). Structural studies in the ArchaeanSargur and Dharwarsupracrustal rocks of the Karnataka craton, Jou. Geol. Soc. Ind., 19, pp. 531-549.

[13] E. V. S. S. K. BABU and D. V. SUBBA RAO (2013). First Finding of Native Gold from the Chromitites of the MesoarchaeanTagadur Mines, Nuggihalli Schist Belt, DharwarCraton, South India, Jou. Geol. Soc. Ind., Vol.81, pp.737-740.

[14] E.B.SugavAnam, C. Malukarjuna, And K.T. Vidyadharan (1994). Archaean Meta Lamprophyres from Nuggihalli Schist Belt, Hassan District - Karnataka. Geol. Soc. India.,Vol. 43, pp.115-137.

[15] Graham R. Hunt (1977). Spectral Signatures of particulate minerals in the visible and near infrared. Geophysics, Vol. 42. No.3, Pp: 501-513.

[16] Huang Zhilong, Liu Chongqiang, Yang Hailing, Xu Cheng, Han Runsheng, Xiao Yunhua, Zhang Bo And Li Wenbo (2002). The Geochemistry Of Lamprophyres In The Laowangzhai Gold Deposits, Yunnan Province, China: Implications For Its Characteristics Of Source Region, Geochemical Journal, Vol. 36, Pp. 91 To 112, 2002.

[17] Hunt and Ashley (1979) Spectra of Altered Rocks in the Visible and Near infrared. Journal of Economic Geology, Volume 74 number 7, Pp1613-1629.

[18] Hunt G.R, JW. Salisbury, C.J, Lenhoff (1971). Visible and Near Infrared Spectra of minerals and Rocks III oxides and Hydroxides,mod, Geo, 2 pp 195-205. 
[19] Hunt, G.R., J.W. Salisbury, and C.J. Lenhoff, 1973, Visible and near-infrared spectra of minerals and rocks: VI. Additional silicates. Modern Geology, v. 4, p. 85-106.

[20] James R.CraigAnd David J.Vaughan (1994). Ore Microscopy and Ore Petrography, pp243 to pp-247.

[21] Joanne.Welton (2003). SEM Petrology Atlas,AAPGPublications,Tulsa.

[22] M. Jayabalan , S. Udayasankar, J. Thiagarajan, S. Sasikumar, E. Nandhakumar, M. Rajakumaran, M. Manikandan And S. Nagamani. (2015). Petrology And Geochemistry Of Lamprophyre Rock Types Of Salem, Dharmapuri, Krishnagiri, And Namakkal Districts, Tamilnadu. Journal Of Applied Geochemistry Vol. 17, No. 2. Pp. 213-235

[23] Maruthi N.E and Basavarajappa H.T (2018). Hyperspectral and Petro - Chemical Signatures study on Corundum Bearing Amphibolite Schist of Magadi Area, Ramanagara District, Karnataka, India. RESEARCH REVIEW International Journal of Multidisciplinary Volume 9, Issue 3, pp. 773-779.

[24] Maruthi N.E and Basavarajappa H.T (2018).HyperspectralAnd Petro - Chemical Signatures Study On Corundum Bearing Litho-Units Of Precambrian Basement Rocks Around Closepect Granite Madhugiri Area, Karnataka, India. Journal of Emerging Technologies and Innovative Research (JETIR) Volume 5, Issue 12, pp. 619 - 628.

[25] Maruthi N.E and Basavarajappa H.T (2018).Hyperspectral Signatures and Petro Chemical Charectistics Study on Corundum Bearing Litho-Units of Sargur Area, Mysuru District, Karnataka, India. International Journal of Research and analytical Reviews (IJRAR) Volume 5, Issue 4, pp. 65-74.

[26] Maruthi N.E, Basavarajappa H.T, Jeevan .L and Siddaraju M.S (2018). Hyperspectral Signatures On Corundum Bearing Litho-Units Of Precambrian Basement Rocks Around Closepet Granite Pavagada Area, Karnataka. International Journal of Computer Engineering and Technology (IJCET) Volume 9, Issue 3, pp. 86-94.

[27] Maruthi N.E, Basavarajappa H.T, Manjunatha M.C, and Harshavardhana A.S. (2019). Hyperspectral Study And Integration Of Petro-Chemical Signatures On Corundum Bearing Litho-Units Around Maddur, Mandya District, Karnataka, India. International Journal of Research and Analytical Reviews (IJRAR), Volume.6, Issue 1, Page No pp.897-903, January -March 2019.

[28] Mecl (2016).Geological Report On Detailed Exploration For Gold InKempinkote Block, Nuggihalli Schist Belt, District: Hassan, Karnataka Pp. 2-60.

[29] Naqvi SM, Rogers JJW (1983). Introduction In: Naqvi S M and Rogers JJW (eds). Precambrian of South India. Geological Society Memorandum, 4, 6-16.

[30] Naqvi, S..M., Sarkar, R.H., SubbaRao, D.V. Govil, P.K. and GnaneswarRao, T (1998). Geology, geochemistry and tectonic setting of Archaean from Karnataka nucleus, India, Precamb. Res., 39, pp. 193-216.

[31] Naqvi, S.M. (1981). The oldest supracrustals of the DharwarCraton, India. Jour.Geol. Soc. India, pp.458-469.

[32] Naqvi, S.M. and Rogers, J.J. W. (1987). Precambrian geology of India. Oxford Univ. Press, Oxford, p.223.

[33] PinakiSengupata, Pradip C Saikia and Prakash C Borthakur (2008). SEM-EDX characterization of an Iron-rich Kaolinite clay. Journal of scientific and Industrial Research Vol 67. Pp 812-818.

[34] Radhakrishna BP (1983). Archean granite-greenstone terrain of the South Indian Shield. In: Naqvi S W and Rogers J J W (eds.), Precambrian of South India. Geological Society of India Memorandum, 4, 1-46. 
Comprehensive Study of Hyperspectrl Signatures, Petrography and Edx Analysis on Gold Bearing Litho Units of Kempinakote, Nuggihalli Schist Belt, Dharwar Craton, Karnataka, India

[35] Radhakrishna BP (1983). Archean granite-greenstone terrain of the South Indian Shield. In: Naqvi S W and Rogers J J W (eds.), Precambrian of South India. Geological Society of India Memorandum, 4, 1-46.

[36] Radhakrishna BP, Naqvi SM (1986). Precambrian continental crust of India and its evolution. Journal of Geology, 94, 145-166.

[37] Ramakrishnan M. and R. Vaidyanadhan. (2008). Geology of India, Volume-1, Pp: 108120.

[38] Santos, L D and Brandno, P R G, 2005. LM, SEM and EDS study of microstructure of Brazilian iron ores, Microscopy and Analysis, 19(1):17-19.

[39] Seshadri, T.S. (1973). Investigation for gold in Kempinkote area, Chennarayapatnataluk, Hassan district, Karnataka state.

[40] Siddaraju M.S, Maruthi N.E and Basavarajappa H.T. Charecterisation And Association Of Molybdenum With Iron Ore Deposit Through Petro-Chemical, Sem And Eds In Rayadurga To Kalyandurga Gap Area Of Closepet Granite DharwarCratonAnantapur District, Andra Pradesh, India. International Journal of Research and Analytical Reviews (IJRAR), E-ISSN 2348-1269, P- ISSN 2349-5138, Volume.6, Issue 1, Page No pp.10771087, January 2019,

[41] Swami Nath. J, Ramakrishnan (1976). Dharwar Stratigraphic model and Karnataka craton.M. andViswanatha, M.N. evolution, Rec. Geol. Surv. India, v.107(2), pp.149-175.

[42] Swaminath J, Ramakrishnan M (1981). Present classification and correlations. In: Swaminath J and Ramakrishnan M (eds.), Early Precambrian supracrustals of southern Karnataka. Geological Survey of India Memorandum, 112, 23-38. 